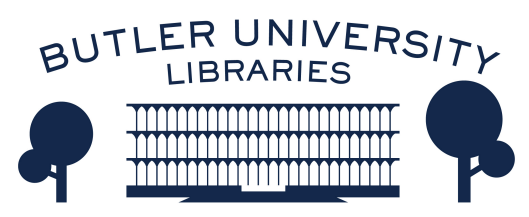

Journal of Hindu-Christian Studies

Volume 24

Article 14

November 2011

\title{
Book Review: "Many Ways of Pluralism: Essays in Honour of Kalarikkal Poulose Aleaz"
}

\author{
M. Moanungsang
}

Follow this and additional works at: https://digitalcommons.butler.edu/jhcs

Part of the Religion Commons

\section{Recommended Citation}

Moanungsang, M. (2011) "Book Review: "Many Ways of Pluralism: Essays in Honour of Kalarikkal Poulose Aleaz"," Journal of Hindu-Christian Studies: Vol. 24, Article 14.

Available at: https://doi.org/10.7825/2164-6279.1491

The Journal of Hindu-Christian Studies is a publication of the Society for Hindu-Christian Studies. The digital version is made available by Digital Commons @ Butler University. For questions about the Journal or the Society, please contact cbauman@butler.edu. For more information about Digital Commons @ Butler University, please contact digitalscholarship@butler.edu. 
bound to raise a number of critical issues, and I wish it would succeed "since the ethic of mutual respect would trump the differences" (p.341).

While what Rajiv states regarding "Dharma scholars" reluctant to turn their gaze and study of the Judeo-Christian tradition (p.345) is largely true today, there have been reformers like Ram Mohun Roy and Dayananda Saraswati who did "turn their gaze" to study western and Islamic religious traditions. Ram Mohun Roy in particular also engaged in debates with Christians and translated the four Gospels into Bengali. He even helped in the establishment of the Calcutta Unitarian Committee. Rajiv's warning that there are no traditional dharma scholars comparable to the westerners trained in "Western seminaries where comparative world religions are seriously taught in order to prepare future leaders with the knowledge necessary to engage with other religions" (p.345) is indeed very true. This lacuna has to be attended to, giving it the highest priority if there has to be any serious dialogue between the two traditions.

This is a book that can be read by those interested in promoting an honest dialogue between different religious traditions. But there are some factual errors which need to be corrected. For instance, note 109 given in the notes on pages 431-32 does not have a corresponding mark within chapter 5 itself. The statement on page 196 that Sri Krishna killed Bhisma is wrong. It was Arjuna's arrows that pierced Bhisma. Krishna only advised Arjuna to place Sikhandin in front so that Bhisma could not retaliate by shooting back with arrows, as it would first kill Sikhandin before reaching Arjuna. Why Bhisma would not kill Sikhandin is too complicated to be narrated here. Page 399 n.51 has Sayanacarya spelt incorrectly as Sayabacharya. However these lapses are very few and far between and cannot substract from the overall wealth and richness of information that is packed into this book. In a larger sense both Hindus and followers of other religions can benefit from reading this book, if done with an open mind. A lot of not so well known facts regarding the different religious traditions are covered. One hopes that in this age of globalization when the world is becoming one 'flat land' mutual respect for the cultures of different peoples will come sooner rather than later. Books of this kind might help in that direction.

T. S. Rukmani

Concordia University

\section{Many Ways of Pluralism: Essays in Honour of Kalarikkal Poulose Aleaz, Edited by V. J. John, 2010, Delhi: ISPCK \& Bishop's College, pp. $\mathrm{x}+347$. ISBN: 978-81-8465-045-7.}

MANY Ways of Pluralism is a festschrift published in honor of Rev. Dr. K. P. Aleaz who has been serving for the past thirty-two years at Bishop's College, Kolkata. This volume consists of eighteen essays contributed by his contemporaries, associates and students as a tribute to a committed professor and renowned scholar for his enormous contribution to theological education, particularly through his extensive writings in the areas of Indian Christian theology and theology of religions.

The content of the book is categorized into two parts. In the first section the various writers explore pluralistic inclusivism from the perspectives of the different disciplines such as:
Christology, Subaltern and Dalit perspectives, Christian Education, Missiology and Spirituality. The various essays in the second section emphasize considering the differing contexts of India as essential in the task of theologizing, such as disability, marginalization, pluriform religiosity and primal traditions. Scholars from diverse backgrounds and traditions have explored whether pluralistic inclusivism can offer relational pro-existence in a multi-cultural and multi-religious context to overcome violence.

The book begins with D. Isaac Devadoss's essay on "Life and Evolution of K.P Aleaz's Thought." The first section deals with his early 
life, theological education, vocation and influences. In the second section, he has identified Aleaz's understanding of Advaita Vedantic thought in the broader context of a few Indian theological articulations. His Christology, based on Sankara's Advaita Vedanta, explains his theology receiving the insights of the Jiva-Brahman relation. The scholar's appreciation for Brahmabandav Upadhyaya's position on Saccidananda and Maya, K. Subba Rao's interpretation of the work of Christ, Samartha's Theo-centric, Mysterycentered Christology and others are clearly highlighted.

S. Robertson in his assessment on "Theological Contributions of K.P. Aleaz" identifies Aleaz's understanding of religion that focuses on the pursuit of relational convergence of religion. However it needs to provide space for religions and ideologies which believe in the non-existence of God, yet committed to the lifesustaining relational convergence of religions. Another evaluation is on Aleaz's focus only on Advaita for strengthening relational convergence rather than seeking for a systematic and gradual development of theological thinking. The religious value of the other is upheld while limiting himself to a select few concerns. The writer draws various constructive insights from Aleaz's Indian Christian thought which portrays his eagerness for religious harmony - the authenticity of all religions in their own context and polarity of religions as natural, openness to dialogical approach while upholding pluralistic inclusivism which perceives all the religious resources of the universe as the common property of all.

In his article "Pluralistic Inclusivism and the Search for a Viable Indian Christian Theology of Religions: Some Random Reflections on the Thought of Rev. Dr. Kalarikkal Poulose Aleaz," V. J. John recapitulates Aleaz's several writings on pluralistic inclusivism with the focus on its viability as an appropriate model for an Indian Christian theology of religions. The writer brings out possible limitations in pluralistic Inclusivism such as mono-dimensional perspective of the Indian hermeneutical context, viewing all religious resources as common property, the gospel as emerging, the concept of a universal Jesus, and an exclusive and superior stance of pluralistic inclusivism as the only suitable model. However, the article concludes that Aleaz's articulation of pluralistic inclusivism as the most appropriate model for inter-religious relationships in pluralistic contexts has brought various challenges for our theological reflections.

Sunil M Caleb further discusses the pluralistic inclusivism of Aleaz with special reference to his Christological understanding. In his article "K. P. Aleaz's Perspective on Indian Jesuology: An Evaluation," Caleb attempts to explain the basic methodology of K. P. Aleaz for the study of an Indian Jesuology. The important characteristic of Aleaz's Jesuology related to the person and function of Jesus is described. At the end the writer evaluates the methodology employed in this perspective. Caleb concludes that Aleaz has presented an Indian Jesus on the basis of Sankara's Advaita Vedanta which has enabled us to understand the fullness of Deity that was present in Jesus' bodily from our finite human point of view.

Samuel Longkumer and Philip V. Peacock reflect on the relevance of pluralistic inclusivism with reference to Subaltern and Dalit issues respectively. Samuel Longkumer in his article "Pluralistic Inclusivism: A Critique from Subaltern Perspective" suggests that pluralistic inclusivism must be understood not only from a religious perspective but also from a social perspective. It means to redefine pluralistic inclusivism from the perspective of the excluded and the marginalized, which includes not only the sharing of resources and spiritual experiences but also accepting the marginalized sections of society into our total life. Philip V. Peacock in his article "A Question of Millions and a Million Questions: Reflecting on Pluralistic Inclusivism from a Dalit Perspective" articulates the problems that are offered by pluralistic inclusivism within the context of Dalit theology. He proposes a school of theology of religions which identifies the dynamics of power and the hazards of fixing and fitting dominated traditions. Every tradition must critically evaluate itself to make sure that it promotes justice, equality and community.

T. Swami Raju in his "Inclusive Pluralistic 
Spirituality for Harmonious Inter-faith Relations" lays stress on living out our spirituality. He regarded that to build new spiritualities and enhanced inter-religious relations must be an ongoing quest and vision of every community. It is through inclusive pluralistic spiritualities that harmonious social relations are established, and the writer therefore appreciates the dynamic contribution of Aleaz's pluralistic inclusivism in the theology of religions.

Examining "Christian Education in a Pluralistic Context" the next contributor Amenla Aier noted plurality as a reality, and one of the goals of Christian education is to allow the learners to live a faith-life creatively in a multifaith society. Attitudes of intolerance, suspicion and hatred are the upshot of one's ignorance of other faith traditions. Participation in the community activities enables us to realize ourselves as persons and to appreciate differences. To nourish and live meaningfully together for the common good demands openness in one's approach rather than adhering to one's own beliefs and ideologies.

Laurent W. Ramabason in his "The Pluralist: An Introduction to the Missiology" of cites diverse kinds of pluralists and elucidates John Hick's missions and also expounds God's mission and the missions of religions according to K. P. Aleaz. The writer describes the encounters among pluralists and with other types of mission-doers. In the conclusion the essential possibilities of the Missiology of religion is discussed. Like other types of mission-doers pluralists are born and come into being as mission-doers. The study of mission-doers embraces a better way of knowing and understanding respective conceptions of the Divine in other traditions and cultures.

"Reading Pluralistic Inclusivism with Aleaz and Beyond" added by T. Jacob Thomas highlights the limitations of classical interpretation of theology of religions and the need for pluralistic inclusivism to acknowledge the multiplicity of religious means and ends as the way forward in a post-modern world. The quest for absolute truth generates totalitarianism and fundamentalism and not human transformation; therefore he defines the world as relationality and the plural end as salvation. Human life in its plurality becomes meaningful when we identify the multiplicity of religious means and ends.

The second section of the book begins with A. Wati Longchar's article on "Culture, Sin, Suffering and Disability in Society." He considers the importance of an inclusive theology that embraces the weaker section in society, particularly the disabled. He examines the cultural beliefs and attitudes towards such groups of people and the connection set by the churches between disability and sin. Churches will continue to be a disabled community unless we include persons with disabilities to have every opportunity to involve meaningfully and get nurtured towards fulfillment.

Raja Ram Mohan Roy's Christology as a model of a contextual articulation from an Indian setting is presented by Ravi Tiwari in his article "Christology of Raja Ram Mohan Roy." The writer notes the efforts taken by Raja Ram Mohan Roy towards the moral and spiritual reformation of human society and his willingness to discover, employ and absorb anything that is common in the religious traditions of his time for accomplishing his goal, though he faced many attacks from conservative groups.

"An Interpretation of Visual reality in relation to Gita, Gospel and Google" by Rajan C. Thomas provides a 'visual reality' concept in Gita, Gospel and Google. The Gita gives us an idea about 'what is delusion', and gospel offers 'illumination', and Google enchants us in illusion, making us to believe that virtual reality is the real reality. The Gita and Gospel reforms and transforms our approach to reality respectively, therefore informing us about the ultimate goal of life. Google 'upforms' the viewer about the reality, and the so-called information confuses us. Various aspects of visual reality in the form of our perception of reality, the problem of the subject-object, the concept of time and space and a prospective solution are systematically discussed in the essay.

The following three writers mark the relevance of the primal religious tradition for an all-encompassing religion in a pluralistic setting. 
"Orientalists and Intertextuality: A Study of Primal Religion in India" by Atola Longkumer finds the inter-textual reading of the texts of the Nagas written by natives and orientalists as a functional resource for the study of primal religion in India. An intertextuality of rereading the orientalists' texts and native's texts helps to examine the past and provide fractional facts of the past in a situation of limited sources within the Ao Naga context. In mutual interaction there is the unfolding of the wisdom for the present day necessitating a collective meaning-making process as mutual unlearning, re-learning and learning. In "Tribal Mythical Resource for a Religious Search," T. Vanlaltlani locates tribal oral mythical stories of the Bru of Mizoram resourceful for theologizing, as they have a great religious value and heritage. Such resources can bring transformation in socio-cultural and economic life as the society struggles to wrestle with the impact of modernization or postmodernization and its implications. Another tribal scholar, H. Chongloi, in his article "Eliade's Methodological Notions Towards a Theology of Religions and the Application of it in the Christian-Kuki Primal Tradition Interaction" asserts that it is in the integral relationship of religions that inter-religious understanding and co-operation will develop. Considering Eliade's methodology and theology of religions as the centre, he attempts to bring out the integral relationship of Christianity with the Kuki Primal tradition.

In "Jesus and Multiculturalism: A Johannine Perspective" V. J. John reflects on Jesus' interactions with the Jews, Greeks and Samaritans in the Gospel of John as a possible biblical model towards our involvement in multicultural settings. Jesus's Jewish background did not hinder his relations to diverse cultural traditions, and this provides a model that confronts the world with an alternate reality of love, care and service in a world of hatred, violence and selfishness. Instead of condemnation or mere imitation of the dominant cultural practices and values the focus needs to be on the conversion of all cultures for the transformation of peoples and structures where peace and justice will reign.

J. Jayakiran Sebastian in his essay "Overcoming Ignorance and Arrogance: Public Theology in Multicultural Context" proposes conquering ignorance and arrogance as the approach to public theology in a multi-cultural and multi-religious context. To overcome ignorance and arrogance the challenges he proposes includes the following: Integration of a multicultural way of thinking in various theological thinking and theological disciplines, promotion of praxiologically-oriented theological education, commitment to a life of sensitive faithfulness, and discernment of issues that impact relationships.

K.P. Aleaz attempts to respond to all the queries presented in the articles. Rev. D. Isaac Devadoss's systematic presentation of a Bibliography of all the writings K. P. Aleaz will unquestionably benefit any interested reader, particularly the researchers. At the end there is a note about the contributors. This collection of essays based on pluralistic inclusivism is an important addition to the study of theology of religions, especially to the students of Indian religious traditions. The various articles also help us to re-examine our stance for promoting greater inter-religious harmony. At the same time it has to be admitted that all the dimensions of Aleaz's theological contributions are not appropriately studied in this book. For example, his contribution to Indian Christian Pramanas, specially his Sabda method of Biblical hermeneutics and his re-conception of Eastern Christian theology in terms of Advaita Vedanta. Even his unique Christology, interpreting Jesus as the re-presentation of the pervasion, illumination and unification of the Atman at all the levels and layers of human personality as well as the whole creation, has not been analyzed appropriately. Perhaps we may have to wait for another volume from his former pupils, devoted exclusively to interpret in detail the theology of K. P. Aleaz.

Moanungsang, D.Th. Scholar

NIIPGTS, Kolkata 